\title{
Article \\ Detection of Oenological Polyphenols via QCM-D Measurements
}

\author{
Mariacristina Gagliardi ${ }^{1}$, Giorgia Tori ${ }^{1}$, Matteo Agostini ${ }^{2}$, Francesco Lunardelli ${ }^{1}$, Fabio Mencarelli ${ }^{3}$, \\ Chiara Sanmartin ${ }^{3,4}\left(\mathbb{1}\right.$ and Marco Cecchini ${ }^{1,2, *} \mathbb{1}$
}

1 NEST, Istituto Nanoscienze-CNR and Scuola Normale Superiore, Piazza San Silvestro 12, I-56127 Pisa, Italy; mariacristina.gagliardi@nano.cnr.it (M.G.); g.tori2@studenti.unipi.it (G.T.); francesco.lunardelli@sns.it (F.L.)

2 INTA S.r.l., Intelligent Acoustics Systems, Via Nino Pisano 14, I-56122 Pisa, Italy; m.agostini@intasystems.net

3 UNIPI Department of Agriculture Food Environment, University of Pisa, Via Del Borghetto 80,

I-56124 Pisa, Italy; fabio.mencarelli@unipi.it (F.M.); chiara.sanmartin@unipi.it (C.S.)

4 Interdepartmental Research Center, Nutraceuticals and Food for Health, University of Pisa,

Via Del Borghetto 80, I-56124 Pisa, Italy

* Correspondence: marco.cecchini@nano.cnr.it

check for

updates

Citation: Gagliardi, M.; Tori, G.;

Agostini, M.; Lunardelli, F.;

Mencarelli, F.; Sanmartin, C.;

Cecchini, M. Detection of

Oenological Polyphenols via QCM-D

Measurements. Nanomaterials 2022,

12, 166. https://doi.org/10.3390/

nano12010166

Academic Editor:

Sivashankar Krishnamoorthy

Received: 19 November 2021

Accepted: 29 December 2021

Published: 4 January 2022

Publisher's Note: MDPI stays neutral with regard to jurisdictional claims in published maps and institutional affiliations.

Copyright: (C) 2022 by the authors. Licensee MDPI, Basel, Switzerland. This article is an open access article distributed under the terms and conditions of the Creative Commons Attribution (CC BY) license (https:// creativecommons.org/licenses/by/ $4.0 /)$.

\begin{abstract}
Polyphenols are a family of compounds present in grapes, musts, and wines. Their dosage is associated with the grape ripening, correct must fermentation, and final wine properties. Owing to their anti-inflammatory properties, they are also relevant for health applications. To date, such compounds are detected mainly via standard chemical analysis, which is costly for constant monitoring and requires a specialized laboratory. Cheap and portable sensors would be desirable to reduce costs and speed up measurements. This paper illustrates the development of strategies for sensor surface chemical functionalization for polyphenol detection. We perform measurements by using a commercial quartz crystal microbalance with dissipation monitoring apparatus. Chemical functionalizations are based on proteins (bovine serum albumin and gelatin type A) or customized peptides derived from istatine- 5 and murine salivary protein- 5 . Commercial oenological additives containing pure gallic tannins or proanthocyanidins, dissolved in water or commercial wine, are used for the analysis. Results indicate that selected functionalizations enable the detection of the two different tannin families, suggesting a relationship between the recorded signal and concentration. Gelatin A also demonstrates the ability to discriminate gallic tannins from proanthocyanidins. Outcomes are promising and pave the way for the exploitation of such devices for precision oenology.
\end{abstract}

Keywords: polyphenols; quartz crystal microbalance; biosensor; functionalization; precision oenology; acoustic wave sensor

\section{Introduction}

Gravimetric sensors based on acoustic waves are fast and reliable tools for a highprecision detection of mass, viscosity, conductivity, and density [1]. Sauerbrey reported, for the first time in 1959, the detection of a substance deposited on a vibrating element (resonator) via acoustic devices [2]. To date, acoustic transducers find application in the manufacturing of a variety of sensors, such as the quartz crystal microbalance (QCM), Rayleigh wave sensors, shear-horizontal surface acoustic wave sensors, Love wave sensors, and several other devices. The QCM is a tool using a piezoelectric resonator to generate bulk acoustic waves (BAW). BAWs propagate inside the resonator and their frequency changes when an event, such as the adsorption of a molecule over sensor surface or a chemical reaction involving the analyte, occurs [3,4]. BAWs in QCM have a shear-horizontal polarization, and this makes them compatible with real-time measurements in a liquid environment [5]. In a typical biosensor, a biologically active molecule (probe) decorates a surface exposed to the sample [6,7], and interacts with the analyte [8]. Due to their versatility and high performance, acoustic-wave-based biosensors find a variety of applications, such as for the detection of proteins [9-11] and enzymes [12-14] and for fast diagnostics [15]. 
To date, there has been a growing interest in the exploitation of acoustic sensors in food science [16], opening the way to new sciences such as precision oenology [17].

Polyphenols are a family of compounds present in grapes, musts, and wines. Their dosage is associated with the grape ripening, correct must fermentation, and final wine properties. Owing to their anti-inflammatory properties, they are also relevant for health and have the potential to reduce risks for cardiovascular, or other non-communicable diseases [18-20]. Wine is a complex matrix containing several hundreds of compounds such as, among others, water, ethanol, organic acids, carbohydrates, and polyphenols [21,22]. Tannins and anthocyanins are extremely important polyphenols, especially for red wines [23], determining most of their organoleptic properties [24]. Currently, polyphenol concentration is monitored by sampling berries, must, or wines $[25,26]$. Collected samples are afterwards analyzed by a traditional chemical analysis $[27,28]$. The extensive monitoring of winemaking process is ideally needed to obtain high quality products, but associated costs would be too high. Easy-to-use and low-cost analytic tools can overcome this limitation.

QCM-D was already used for wine analysis, with ad hoc experiments exploring the role of positively and negatively charged functional groups [29] and different polymeric functionalizations [30]. Cited works have demonstrated that hydrophilic and negatively charged groups $\left(-\mathrm{SO}_{3} \mathrm{H}\right.$ and $\left.-\mathrm{COOH}\right)$ have the best ability to adsorb red wine constituents, while the hydrophilic non charged groups $-\mathrm{OH}$ show the worst performance. On the other hand, in polymeric layers, $-\mathrm{NH}_{2}$ and $-\mathrm{COOH}$ promoted adsorption of constituents from white wines, $-\mathrm{OH}$ exhibited a strong preference for rosé wines and the acrylic acid for the red wine. These results indicate that the selective adsorption of components over the functional layer is a complex phenomenon that does not depend only on the exposed functional groups. QCM-D was also used for the analysis of potential wine contaminations [31], and to study the interactions between wine compounds and salivary proteins [32-34], with the fascinating aim to compare measured data with the human mouthfeel [35]. To the best of our knowledge, QCM-D has not yet been used for wine polyphenol detection.

A valid probe molecule for wine polyphenol detection can be selected among the agents used for wine refinement, a process performed to make the final product clear [36] and less subject to oxidation [37]. Tannic acid, the unit constituting several polyphenols, forms colloidal solutions when it interacts with molecules forming hydrogen bonds [38]. Proteins can establish Van der Waals interactions [39], thus are used in wine refinement for their ability to form complexes with polyphenols, giving stable colloidal solutions [40].

In this work, we present a potentially powerful, cheap, and fast approach for the quantification of polyphenols. With this aim, we investigate four functionalizations for QCM-D sensors: (1) bovine serum albumin (BSA); (2) type A gelatin for porcine skin (Gel-A); (3) the synthetic low-molecular-weight peptide called istatine-5 (Ist-5); and (4) a peptide fragment of the murine salivary protein-5 (MP-5). Such functionalizations are tested with watery and winery solutions, containing polyphenols. BSA, already tested in QCM-D experiments with gallic tannins from green tea [41,42], can interact with free polyphenols forming soluble complexes [43] with a high efficiency [44], and the complexation mechanism is already well known [45]. Moreover, BSA has a great ability to form complexes with high-molecular-weight polyphenols [46], and this ability makes BSA also a good candidate in the detection of tannins condensed after oxidative processes. Gel-A is used to lower the overall polyphenols content in wines, reducing astringency more than other proteins $[47,48]$. This protein has already been used in QCM-D experiments to evaluate the astringency in beer [49]. Ist-5 is a small peptide with a larger ability to precipitate tannins than proline-rich proteins [50]. Its aminoacidic sequence has a potential to form useful interactions with tannins [51], establishing strong interactions with the aromatic rings of condensed proanthocyanidin tannins [52]. MP-5 is a proline-rich peptide derived from the whole murine salivary protein-5 [53], and it has great affinity for hydrolysable gallic tannins [54]. 


\section{Materials and Methods}

\subsection{Reagents}

1,4-Dithiothreitol (DTT) was used as reducing agent for thiolated molecules (Sigma Aldrich, St. Louis, MO, USA); 12-mercaptododecanoic acid (12-MCA, $\mathrm{M}_{\mathrm{w}} 232.4 \mathrm{Da}$, purity degree 96\%) as linker for proteins (Sigma Aldrich); bovine serum albumin (BSA, $\mathrm{M}_{\mathrm{w}} 66.5 \mathrm{kDa}$ ) and gelatin from porcine skin type A (Gel-A, High bloom $\left.\mathrm{M}_{\mathrm{w}} 75.0 \mathrm{kDa}\right)$ as functionalizing proteins (Sigma Aldrich); istatine-5 (Ist-5, amino acid sequence: DSHAKRHHGYKRKFHEKHHSHRGYC, $\left.\mathrm{M}_{\mathrm{w}} 3139 \mathrm{Da}\right)$ and murine salivary protein-5 (MP-5, GPQQRPPQPGNQQGPPPQGGPQC, $\mathrm{M}_{\mathrm{w}} 2350 \mathrm{Da}$ ) with C-terminal cysteine (both synthesized by Biomatik Kitchener, Ontario, Canada, purity degree 95\%) as functionalizing peptides; N-(3-Dimethylaminopropyl)-N'-ethylcarbodiimide hydrochloride (EDCl) and Nhydroxyssuccinimide (NHS) as coupling agents (Sigma Aldrich, purity degree $\geq 98 \%$ ); commercial Italian wine Tavernello (production lot no. LA1050MO), oenological tannin commercial blends TANIN GALALCOOL (TG, polyphenol content > 95\%), TANIN VR SUPRA (TS, >65\%) TANIN GALALCOOL SP (TGSP, >95\%), TANIN VR GRAPE (TGR, $>65 \%$ ) (LAFFORT ${ }^{\circledR}$, Bordeaux, France), and Enartis TAN BLANC (TB, Esseco S.r.l., San Martino Trecate NO, Italy, Enartis Division, polyphenol content n.a.) for the preparation of samples. All reagents were used as received.

\subsection{Quartz Crystal Microbalance with Dissipation Monitoring (QCM-D) Experiments}

QCM-D (E4 model, Q-Sense AB, Sweden) measurements were performed with polished AT-cut quartz crystals (gold electrodes, fundamental resonance frequency $f_{0}=5 \mathrm{MHz}$, diameter $=14 \mathrm{~mm}$, thickness $=100 \mathrm{~nm}$ ) in static mode (stop flow), with fluidic cells thermostated at $25^{\circ} \mathrm{C}$. This apparatus allows recording simultaneously the resonance frequency shift $(\Delta f)$ and energy dissipation $(\Delta D)$ for up to 13 overtones by exciting the fundamental resonance frequency of the crystal. In this work, the 3rd overtone was chosen as the most sensitive and stable among the entire dataset. In addition, we checked if $\Delta D$ values were suitable for the application of the Sauerbrey model. According to [55], one of the proposed criteria to check is to have $\Delta D<2.0 \times 10^{-6} . \Delta D$ values are strictly related to the mechanical behavior of the functionalization adlayer. In our case, the Sauerbrey equation would only be valid for the functionalization with peptides. However, our main interest is in the sample detection; thus, we decided to use the Sauerbrey model also for proteins, with a slight underestimation of calculated areal masses.

\subsection{Sensor Surface Functionalization}

The gold surface of the crystal quartz was modified by covalently attaching the functional layer on the surface. The covalent bonds were obtained by the thiol-gold chemistry.

For the functionalization with proteins that do not contain free thiol groups for the thiol-gold reaction, the 12-MCA was used as linker in a two-step functionalization (Figure 1a). 12-MCA was solubilized $\left(1 \mathrm{mg} \mathrm{mL}^{-1}\right)$ in a 1:1 $v / v$ water/ethanol mixture containing DTT $(3.5 \mathrm{x} \mathrm{mol} / \mathrm{mol}$ in respect to free $-\mathrm{SH}$ groups). This solution was injected in the QCM-D chamber and data were acquired for $60 \mathrm{~min}$ in static mode, then the sensors were rinsed first injecting a 1:1 water/ethanol solution (data acquisition $5 \mathrm{~min}$ ), then pure water $(5 \mathrm{~min})$. This procedure allowed obtaining a 12-MCA self-assembled monolayer (SAM) with the carboxylic functionalities exposed toward the water phase, and available for the following protein conjugation. In the second functionalization step, BSA or Gel-A were dissolved $\left(1 \mathrm{mg} \mathrm{mL}^{-1}\right)$ in a solution of EDCl/NHS $(50 \mathrm{mM})$ in ultrapure water. Solutions were injected in the QCM-D chamber and data were acquired for $60 \mathrm{~min}$, then the sensors were rinsed with ultrapure water $(10 \mathrm{~min})$. For sensor functionalization with peptides (Figure $1 \mathrm{~b})$, Ist- 5 or MP-5 solutions in water $\left(1 \mathrm{mg} \mathrm{mL}^{-1}\right)$ containing DTT $(3.5 \mathrm{x} \mathrm{mol} / \mathrm{mol}$ in respect to free $-\mathrm{SH})$ were injected in the QCM chamber $(60 \mathrm{~min})$ then rinsed with water (5 min). Prior to use, quartz crystals were treated with plasma oxygen (Femto Diener) for $10 \mathrm{~min}$ at a power of $100 \mathrm{~W}$, immersed in a 5:1:1 solution of water, ammonia $(32 \% \mathrm{v} / \mathrm{v})$, 
and oxygen peroxide $(25 \% \mathrm{v} / \mathrm{v})$ at $75^{\circ} \mathrm{C}$ for $15 \mathrm{~min}$, rinsed with water and after with isopropanol, and treated with plasma oxygen again $(10 \mathrm{~min}, 100 \mathrm{~W})$.
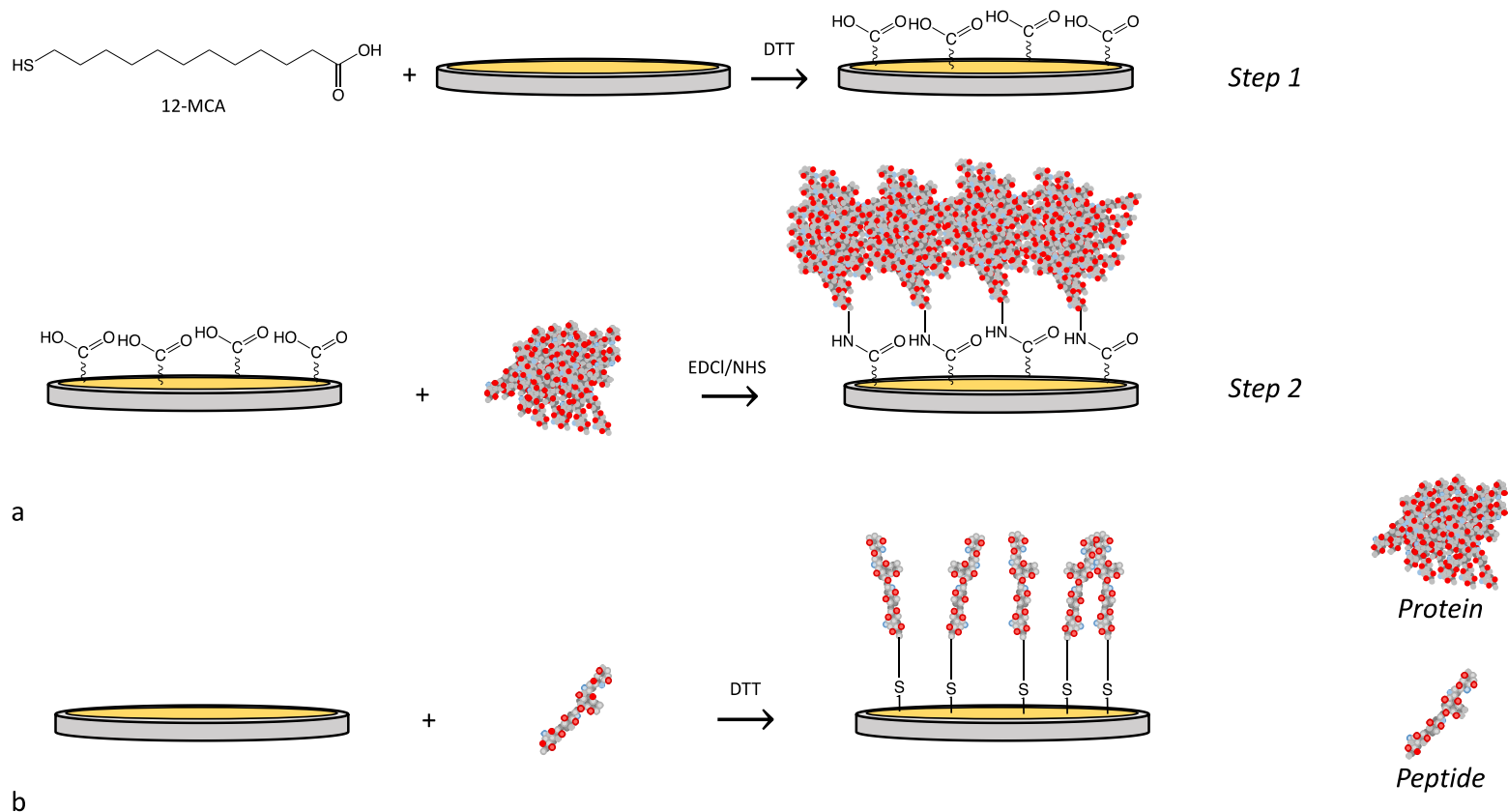

Figure 1. QCM-D functionalization strategies: (a) two-steps functionalization with proteins, (b) functionalization with peptides.

\subsection{Detection Experiments}

Aqueous solutions of TG and TS were obtained dissolving the tannin blends in water. Solutions with fixed tannin concentrations (Table 1) were prepared, filtered with a $1.2 \mu \mathrm{m}$ filter syringe, and the $\mathrm{pH}$ was measured. Eventually, samples were stored at $4{ }^{\circ} \mathrm{C}$ before use.

Table 1. Aqueous solutions used for QCM-D measures: sample nomenclature, commercial tannin blend dissolved in water, polyphenol concentration (calculated), and measured $\mathrm{pH}$.

\begin{tabular}{cccc}
\hline Sample Nomenclature & Commercial Tannin Blend Added & Polyphenol Concentration/g L & $\mathbf{p H}$ \\
\hline TG-Low & & 0.02 & 4.93 \\
TG-Mid & TANIN GALALCOOL & 0.10 & 4.32 \\
TG-High & & 0.19 & 4.13 \\
TS-Low & TANIN VR SUPRA & 0.07 & 5.76 \\
TS-Mid & & 0.26 & 4.91 \\
TS-High & & 0.52 & 4.91 \\
\hline
\end{tabular}

Sample analysis of watery samples was performed by injecting three TG or TS solutions at increasing concentrations. Data were acquired in static flow for $15 \mathrm{~min}$ for each injected sample, then the sensors were rinsed with water and data acquired for a further $5 \mathrm{~min}$.

Winery samples (Table 2) were prepared by adding the tannin blends in a commercial white wine, previously characterized following the official methods (OIV 2021) (alcoholic degree $10.41 \pm 0.01 \%$ vol.; $\mathrm{pH}=3.16 \pm 0.01$; titratable acidity $=5.30 \pm 0.02 \mathrm{~g} / \mathrm{L}$ as tartaric acid; net volatile acidity $=0.21 \pm 0.01 \mathrm{~g} / \mathrm{L}$ as acetic acid). Samples were then stabilized, filtered with a $1.2 \mu \mathrm{m}$ filter syringe, the $\mathrm{pH}$ was measured, then samples were stored at $4{ }^{\circ} \mathrm{C}$ before use. 
Table 2. Winery solutions used for QCM-D measurements: sample nomenclature, commercial tannin blend added to the base wine, polyphenol concentration measured via UV spectrophotometry (reading at $280 \mathrm{~nm}$ ) and with the Folin-Ciocalteu method, proanthocyanidins concentration measured via the Bate-Smith method, measured $\mathrm{pH}$; each value represents mean \pm standard deviation $(n=3)$.

\begin{tabular}{|c|c|c|c|c|c|}
\hline \multirow[t]{2}{*}{ Sample Nomenclature } & \multirow[t]{2}{*}{ Commercial Tannin Blend Added } & \multicolumn{2}{|c|}{$\begin{array}{c}\text { Polyphenol Concentration } \\
\text { (g L }{ }^{-1} \text { Gallic Acid Equivalent) }\end{array}$} & \multirow{2}{*}{$\begin{array}{l}\text { Proanthocyanidins Concentration } \\
/ \mathrm{mg} \mathrm{L}^{-1} \text { Epicatechin Equivalent }\end{array}$} & \multirow[b]{2}{*}{$\mathbf{p H}( \pm \mathbf{0 . 0 5})$} \\
\hline & & $\mathrm{UV} / \mathrm{g} \mathrm{L}^{-1}$ & Folin-Ciocalteu & & \\
\hline A & - & $0.14 \pm 0.01$ & $0.22 \pm 0.01$ & $50 \pm 2$ & 3.16 \\
\hline C3 & \multirow{2}{*}{$\mathrm{TB}$} & $2.64 \pm 0.02$ & $2.21 \pm 0.09$ & $45 \pm 2$ & 3.34 \\
\hline C5 & & $5.47 \pm 0.14$ & $4.14 \pm 0.07$ & $55 \pm 2$ & 3.15 \\
\hline G2 & \multirow{4}{*}{ TG } & $0.96 \pm 0.01$ & $0.77 \pm 0.01$ & $42 \pm 1$ & 3.20 \\
\hline G3 & & $2.06 \pm 0.08$ & $1.52 \pm 0.07$ & $39 \pm 1$ & 3.14 \\
\hline G4 & & $3.12 \pm 0.12$ & $2.17 \pm 0.10$ & $38 \pm 3$ & 2.93 \\
\hline G5 & & $4.26 \pm 0.10$ & $2.83 \pm 0.01$ & $64 \pm 3$ & 3.00 \\
\hline $\mathrm{H} 2$ & \multirow{4}{*}{ TGSP } & $1.03 \pm 0.03$ & $0.91 \pm 0.01$ & $24 \pm 4$ & 3.04 \\
\hline H3 & & $2.13 \pm 0.09$ & $1.80 \pm 0.09$ & $36 \pm 2$ & 3.11 \\
\hline $\mathrm{H} 4$ & & $3.33 \pm 0.04$ & $2.67 \pm 0.07$ & $45 \pm 6$ & 3.14 \\
\hline H5 & & $4.34 \pm 0.10$ & $3.39 \pm 0.04$ & $53 \pm 5$ & 3.15 \\
\hline I2 & \multirow{2}{*}{ TGR } & $0.93 \pm 0.03$ & $1.74 \pm 0.03$ & $824 \pm 1$ & 2.93 \\
\hline I3 & & $2.01 \pm 0.01$ & $3.81 \pm 0.11$ & $1702 \pm 6$ & 2.89 \\
\hline
\end{tabular}


Polyphenol concentrations in samples were measured via Folin-Ciocalteu and UV-vis spectroscopy (absorbance at $280 \mathrm{~nm}$ ), while proanthocyanidins were quantified with the Bate-Smith method [55-57].

Measurements of winery solutions were performed by injecting one single sample. Data were acquired in static flow for $15 \mathrm{~min}$, then the sensors were rinsed with water and data acquired for a further $5 \mathrm{~min}$.

\subsection{Data Analysis}

At least two experiments were performed for each condition. $\Delta f$ and $\Delta D$ were continuously recorded throughout the whole experiment (sensor, functionalization, detection, and related rinsing). Data are reported as $\Delta f(\mathrm{~Hz}), \Delta D$, and molar areal mass $\left(\mathrm{pmol} \mathrm{cm}^{-2}\right)$. Reported values are the mean values of replicates. Range error bars encompass the lowest and highest values recorded for each condition. Inner fences for large datasets from functionalization experiments were calculated by multiplying the interquartile range (Q1-Q3) by 1.5 .

\section{Results}

\subsection{Functionalization}

We consider the functionalization with protein as the whole layer composed of 12-MCA + protein. QCM-D generated a plot with changes in frequency and dissipation of the experiment sequence that can be followed in real time (Figure 2). Absolute values of $\Delta f$ were higher in functionalization with proteins than in those with peptides (Figure 3a). At the same time, $\Delta D$ (Figure $3 \mathrm{~b}$ ) was higher for proteins than peptides. While for peptides dissipation there were very low values $(\sim 0)$, for Gel-A $\left(3.2 \times 10^{-5}\right)$ and BSA $\left(1.5 \times 10^{-5}\right)$ it reached values slightly higher than values recommended for the application of the Sauerbrey model. This indicates that the peptide adlayer has a rigid behavior, while proteins tend more towards a viscoelastic behavior. Median values of the molar areal mass calculated with the Sauerbrey equation (Figure 3c) were quite similar in all cases (median values are BSA 15 pmol cm ${ }^{-2}$, Gel-A 24 pmol cm ${ }^{-2}$, Ist-5 12 pmol cm ${ }^{-2}$, MP-5 51 pmol cm $^{-2}$ ).
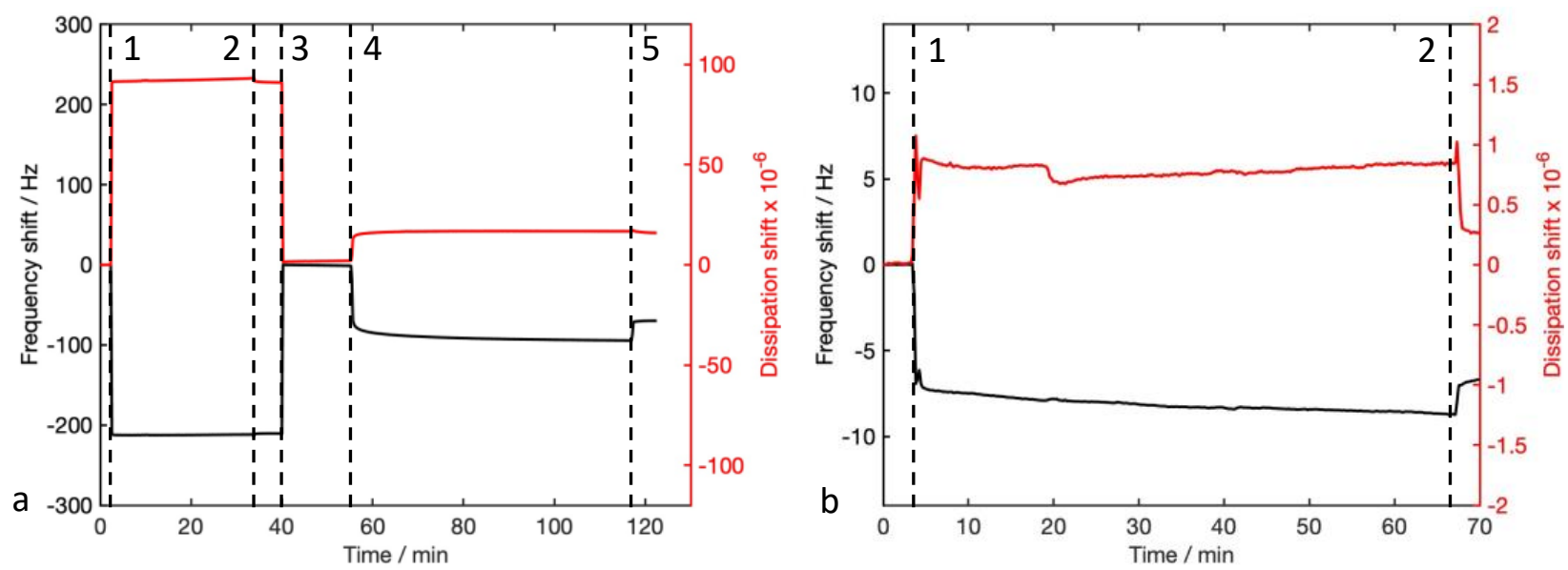

Figure 2. QCM traces of functionalization with (a) proteins, (b) peptides; in functionalization with proteins, 1: injection of the 12-MCA solution, 2: rinsing with $\mathrm{EtOH} /$ water, 3: rinsing with water, 4: injection of the protein solution (in this example, BSA), 5 : rinsing with water; in functionalization with peptides, 1: injection of the peptide solution (in this example, MP-5), 2: rinsing with water. 

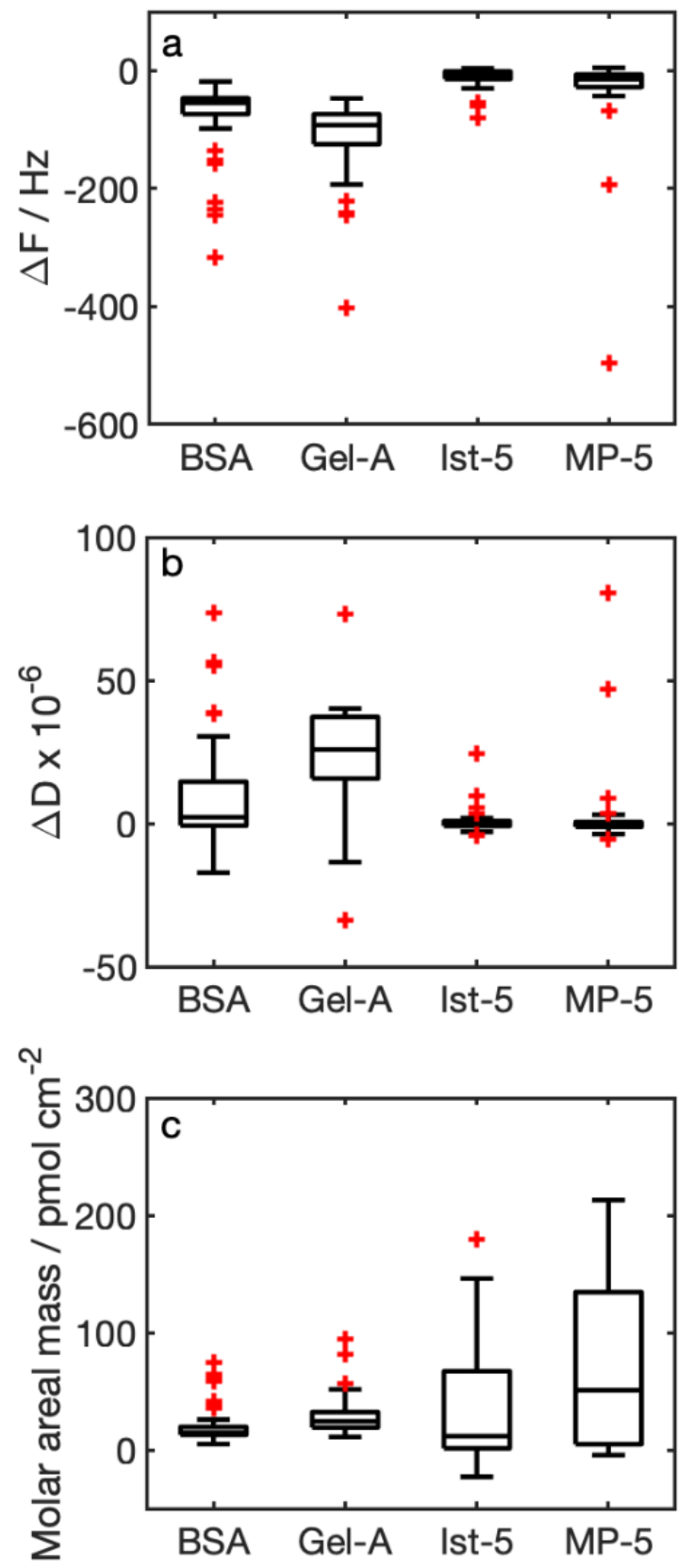

Figure 3. Characterization of SAM: (a) $\Delta f$ (F3), (b) $\Delta D$ (D3), and (c) molar areal mass calculated with the Sauerbrey model; the number of experiments for the statistical analysis is 39 for BSA, 32 for Gel-A, and 30 for Ist- 5 and MP-5. Red crosses are values out of the interquartile range multiplied by 1.5.

\subsection{Watery Samples Detection}

$\Delta f$ measured for watery samples (Figure 4) indicated, in most cases, negative values due to mass loading, and some positive data in the detection of TG with Gel-A (Figure $4 \mathrm{~b}$ ). We registered significant $\Delta f$ after mid-concentration sample injection only in proteinfunctionalized sensors, and not in peptide-functionalized sensors.

Focusing on TG-based samples, the $\Delta f$ plotted against tannin concentration (Figure $5 \mathrm{a}, \mathrm{b}$ ) and sample $\mathrm{pH}$ (Figure $5 \mathrm{c}, \mathrm{d}$ ), showed that data might follow a linear trend in all cases. The same behavior was not verified for TS-based samples (data not shown). 

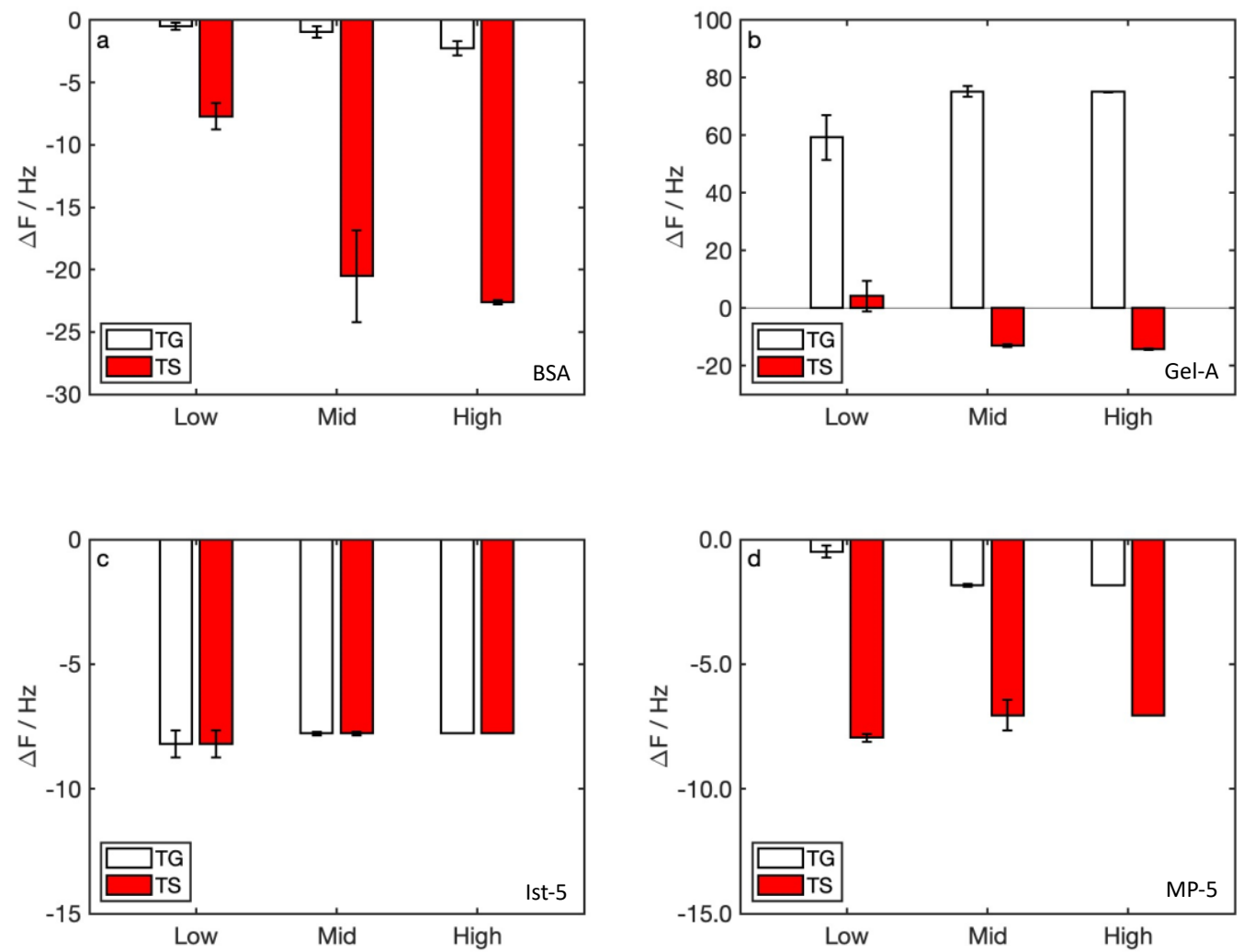

Figure 4. Detection of polyphenols in watery solutions: $\Delta f$ vs. sample concentration (see Table 1 ) in (a) BSA, (b) Gel-A, (c) Ist-5, (d) MP-5.
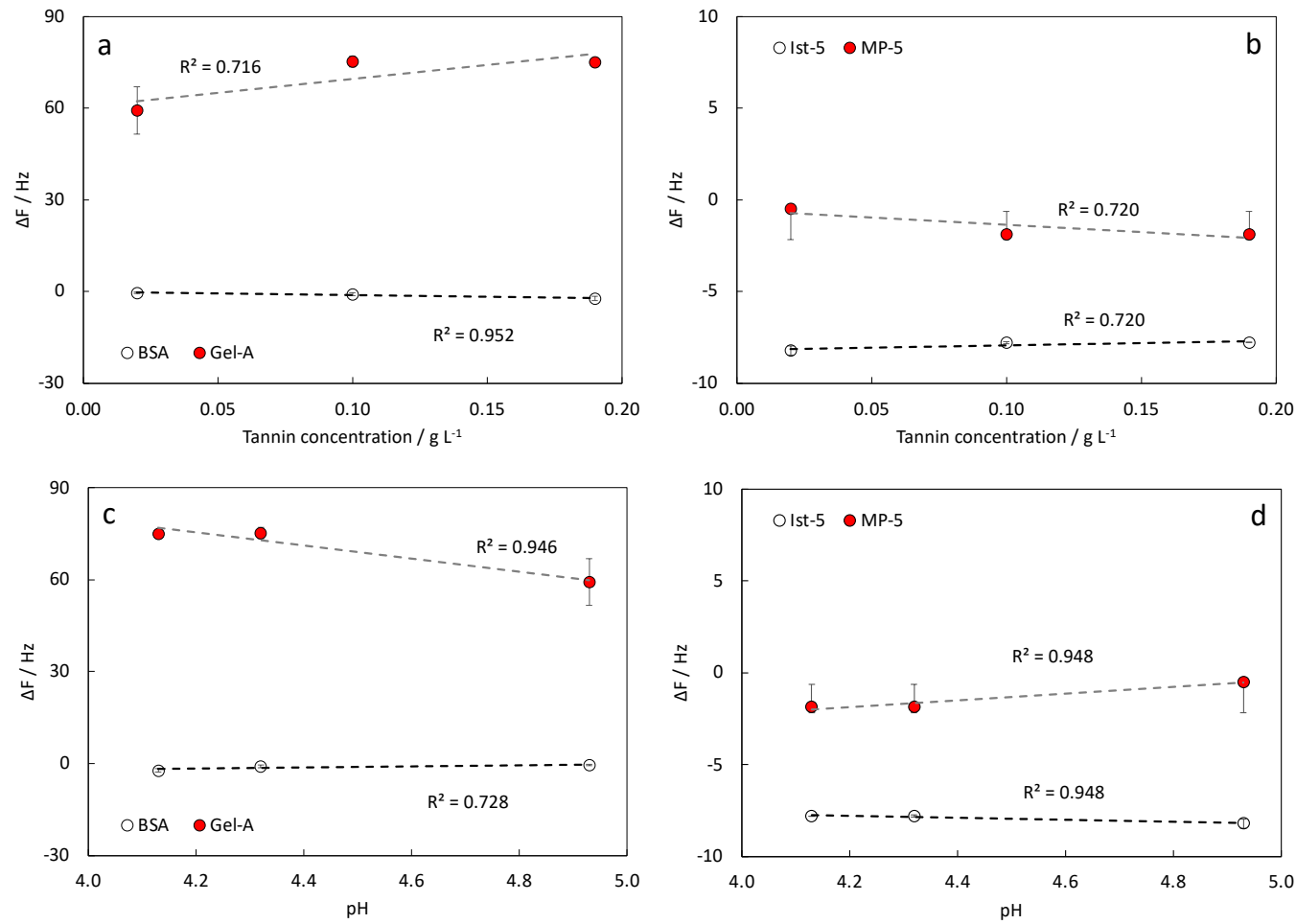

Figure 5. Detection of polyphenols in watery solutions containing TG: $\Delta f$ vs. tannin concentration in (a) proteins, (b) peptides; $\Delta f$ vs. $\mathrm{pH}$ in (c) proteins, (d) peptides. 


\subsection{Winery Samples Detection}

$\Delta f$ measured for winery samples (Figure 6) was quite in line with those measured in watery samples. We measured positive $\Delta f$ for samples with added TG (sample families $G$ and $\mathrm{H}$, see Table 2) with Gel-A, while the same samples provided negative $\Delta f$ with BSA (Figure 6a). $\Delta f$ measured with peptides was negative in all cases (Figure $6 \mathrm{~b}$ ).
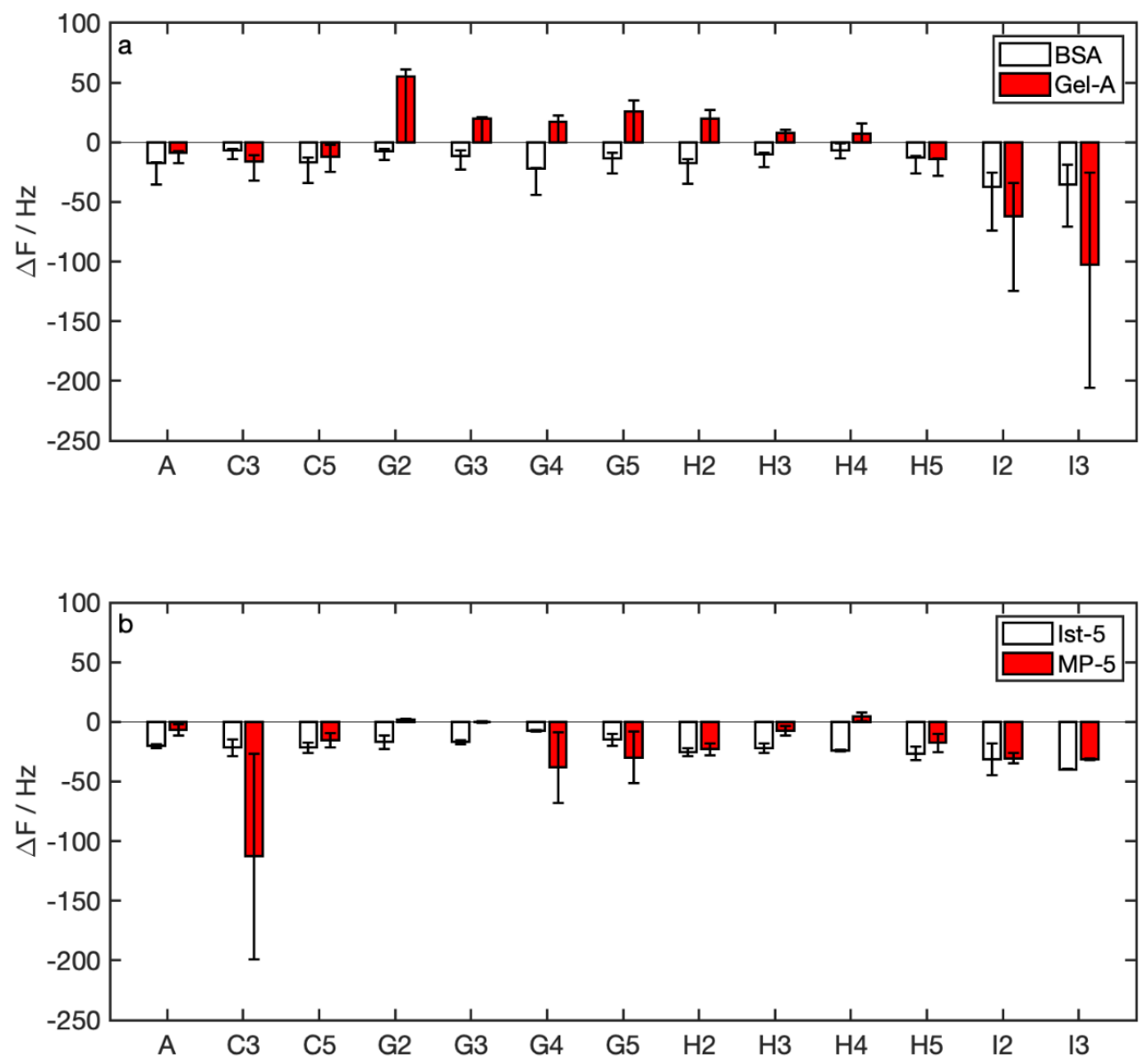

Figure 6. Detection of polyphenols in winery solutions: $\Delta f$ vs. sample nomenclature in (a) proteins, (b) peptides.

$\Delta f$ values measured for samples $\mathrm{G}$ and $\mathrm{H}$ were aggregated and plotted against the measured polyphenol concentration (Folin-Ciocalteu method) and $\mathrm{pH}$ (Figure 7). We found high correlations between values obtained with Gel-A vs. polyphenol concentration and between values obtained with BSA and $\mathrm{pH}$.
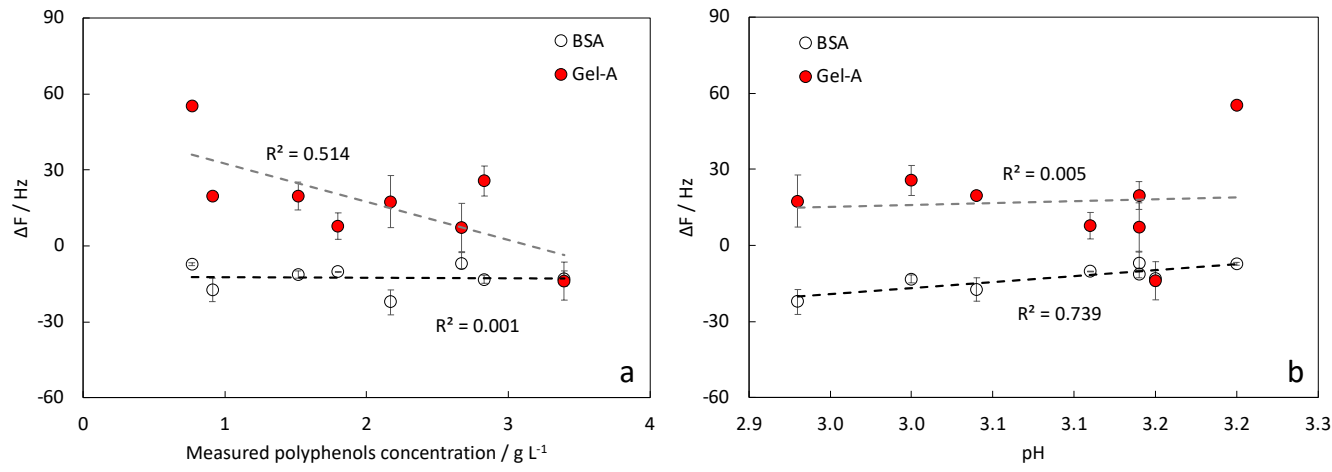

Figure 7. Detection of polyphenols in samples with gallic tannins added (samples G and H, Table 2): (a) as a function of measured polyphenols concentration, (b) as a function of measured $\mathrm{pH}$. 


\section{Discussion}

Absolute values of $\Delta f$ measured for functionalizing adlayers were higher for proteins than for peptides (Figure 3). This could be related to the different molecular weights of molecules used for the functionalization. However, we calculated similar values for molar areal masses, indicating that the functionalization procedure is sufficient to saturate the whole crystal surface and thus leads to comparable results. This makes data obtained in sample analysis comparable to each other.

$\Delta f$ measured for watery samples with BSA were, in all cases, negative (Figure 4a). This represents a common case in QCM-D analysis, in which negative $\Delta f$ are related to the increase of deposited mass due to the interaction between sample and functionalization. With this protein, we measured increasing absolute values of $\Delta f$ in all cases. This indicates that the functionalization adlayer does not reach a saturation with the amounts of tannins loaded. The same effect was not verified with TS, for which the absolute values of $\Delta f$ in the second and in the third measures were quite similar. The different saturation limits detected for TG and TS could be due to sample concentrations, which were higher for TS that TG. Thus, the saturation of the BSA functionalization adlayer was not directly comparable in this case. In measures obtained with Gel-A-functionalized sensors, we found positive $\Delta f$ for TG, and a saturation for the more concentrated sample (Figure $4 \mathrm{~b}$ ). The positive $\Delta f$ can be explained on the basis of the interactions occurring between Gel-A and gallic tannins. As previously stated, proteins can form hydrogen bonds between prolines and functional groups of tannins. Such bonds form an interpenetrating network (IPN), in which macromolecules are physically crosslinked by interactions promoted by tannins. The formation of an IPN makes the adlayer more rigid, and part of the hydration water can be expelled, causing the increase of frequency oscillation in the sensor. The literature already clarifies the role of proline units in the interactions between food proteins and tannins [58]. This intermolecular interaction leads to the formation of a physical crosslinking of proteins [59] and, consequently, to the formation of insoluble protein-tannin complexes [60]. The blocking of hydrophilic amino acid residues (in proteins tested in this work, prolines) with the interacting molecules (tannins) is involved in the protein solubilization [61] and such kind of protein solubility modification causes the displacement of water molecules after the arising of hydrophobic interactions (hydrophobic effect) [62].

In the case of TS samples, which contained higher amounts of tannins relative to $\mathrm{TG}$, the positive $\Delta f$ occurred only for the sample with the lower concentration, then we hypothesized a mass loading, and negative $\Delta f$, for more concentrated samples. In this case, the effect of dehydration was covered by the mass loading. According to this hypothesis, BSA does not form an IPN with tannins, although the interaction would be similar to that formed in the Gel-A functionalization. The different behavior of selected proteins can be explained on their different isoelectric point (BSA 4.7 [63], Gel-A 9.0 [64]). In the range of sample $\mathrm{pH}, \mathrm{BSA}$ works close to its isoelectric point, and then it has a neutral charge favoring the hydrophobic interactions, while Gel-A is under its isoelectric point and becomes positively charged. The different macromolecular charge implies a different interaction with tannins, and the formation of an IPN in BSA is hampered. In measures with peptide-functionalized sensors, we found negative $\Delta f$, both for Ist- 5 and MP-5, for TG and TS (Figure 4c,d). While in Ist-5 sensors the saturation seemed to be reached after the first sample injection, in MP-5 we had increasing signals for TG measures. As a general rule, we find saturation concentrations higher for proteins than for peptides.

The detection of polyphenols in winery samples shows some important similarities with the analysis of watery samples in measures with protein-functionalized sensors (Figure 6). Winery samples belonging to families $\mathrm{G}$ and $\mathrm{H}$ were added with the same tannins contained in the sample indicated as TG. $\Delta f$ obtained with samples $\mathrm{G}$ and $\mathrm{H}$ resulted negative for BSA and positive for Gel-A, in compliance to watery sample analysis. Values of $\Delta f$ are not directly comparable between watery and winery samples because of the different tannin concentrations. 
Focusing our analysis only on $\mathrm{G}$ and $\mathrm{H}$ samples, $\Delta f$ obtained with sensors functionalized with Gel-A could be correlated with the overall polyphenol concentration and not with the $\mathrm{pH}$, while those obtained with BSA-functionalized sensors correlated with the $\mathrm{pH}$ and not with the concentration (Figure 7). This suggests that Gel-A-functionalized sensors are not affected by the $\mathrm{pH}$, making the sensor more reliable. In contrast, BSA-functionalized sensors were affected by the $\mathrm{pH}$ under the isoelectric point. However, due to the nonlinear correlation between $\mathrm{pH}$ and tannin concentrations in winery samples, the functionalization with BSA seems to be unsuitable for such measures. Appreciable $\Delta f$ was obtained with samples I with protein-functionalized sensors, indicating that both functionalizations can be used for proanthocyanidins detection. Gel-A, in particular, was able to discriminate between gallic tannins and proanthocyanidins on the basis of the positive or negative $\Delta f$ obtained.

Sensors functionalized with peptides gave appreciable $\Delta f$ in measures with winery solutions, indicating that interactions between tannins and probe molecules were established. However, the complex wine matrix, also containing ethanol, sugar, and wine proteins, makes the detection more difficult. However, the potential interaction of the whole components of wine on our developed functionalizations is not negligible. To date, we know that the ethanolic content has an important effect only on measure transient, so this compound should be not considered the most responsible for a potential interference. On the other hand, the literature reports that proteins and sugars can strongly interact [65]. A deeper characterization of developed functionalizations involves the analysis of BSA and Gel-A behaviors in the presence of wine sugars (mainly, glucose and fructose, and sucrose to a minor extent). Moreover, proteins are generally accounted for the nonspecific signal in gravimetric sensors, thus suitable strategies to reduce nonspecific adsorption over the free Au surface of the sensitive element (e.g., by increasing hydrophilicity) and the functionalization adlayer (e.g., by blocking with specific molecules) are also needed.

Conventional analytical methods (e.g., HPLC) are well consolidated techniques for tannin concentration quantification [66]. Moreover, results from conventional analytical methods are considered more reliable than those obtained through other techniques, but they also require an elaborated preparation and long analysis time and are often unsuitable for real time analysis [67]. Whilst acoustic sensors show a lower sensitivity in respect to consolidated analytical methods, they can give some easy-to-understand quantitative information. As an example, the tannins/proanthocyanidins balance is an indicator of the astringency, which is a very important property in the characterization of wines. Our experiments showed that this technology can be used as a fast indicator of the potential mouthfeel generated during vinification.

\section{Conclusions}

Selected proteins and peptides used in this work for the functionalization of QCM crystals show a potential in tannins analysis. Surprisingly, protein-based functionalizations are not affected by the wine matrix, thus measures in winery samples are analogous to those obtained for watery samples. Functionalizations with proteins work better than those with peptides, although selected peptides show interesting potential in discriminating proanthocyanidins versus gallic tannins, in particular MP-5.

Taken together, our results indicate that different families of tannins and concentrations can be effectively detected by the proposed functionalization strategies in a sensing platform (the QCM-D) that can be easily miniaturized for portable analysis. Outcomes are promising and pave the way for the exploitation of such devices for precision oenology.

Author Contributions: Data curation, M.G., G.T. and M.C.; Formal analysis, M.G. and G.T.; Funding acquisition, M.C. and F.M.; Investigation, M.G., M.A., F.L., C.S. and M.C.; Methodology, M.G.; Project administration, M.C.; Supervision, F.M. and M.C.; Writing-original draft, M.G.; Writing-review \& editing, G.T., M.A., F.L., F.M., C.S. and M.C. All authors have read and agreed to the published version of the manuscript. 
Funding: This research was funded by: the Italian Ministry of University and Research (MUR) with the project "VioLOC-Wine and Oil Analysis 4.0: development of a Lab-On-Chip with remote connectivity"-FISR 2019, Grant FISR2019-03020; Fondazione Cassa di Risparmio di Lucca with the project "SAWine: Lab-on-a-Chip based on Surface Acoustic Waves for precision oenology".

Data Availability Statement: The data presented in this study are available on request from the corresponding author.

Conflicts of Interest: The authors declare no conflict of interest.

\section{References}

1. Zhang, J.; Zhang, X.; Wei, X.; Xue, Y.; Wan, H.; Wang, P. Recent advances in acoustic wave biosensors for the detection of disease-related biomarkers: A review. Anal. Chim. Acta 2021, 1164, 338321. [CrossRef]

2. Sauerbrey, G.Z. Use of quartz vibration for weighing thin films on a microbalance. Z. Phys. 1959, 155, 206-212. [CrossRef]

3. Karunakaran, C.; Rajkumar, R.; Bhargava, K. Introduction to biosensors. In Biosensors and Bioelectronics; Elsevier: Amsterdam, The Netherlands, 2015; pp. 1-68.

4. Jang, I.R.; Jung, S.I.; Lee, G.; Park, I.; Kim, S.B.; Kim, H.J. Quartz Crystal Microbalance with Thermally-controlled Surface Adhesion for an Efficient Fine Dust Collection and Sensing. J. Haz. Mater. 2021, 424, 127560. [CrossRef] [PubMed]

5. Kanazawa, K.K.; Gordon, J.G. Frequency of a quartz microbalance in contact with liquid. Anal. Chem. 1985, 57, 1770-1771. [CrossRef]

6. Wasilewski, T.; Szulczyński, B.; Kamysz, W.; Gębicki, J.; Namieśnik, J. Evaluation of three peptide immobilization techniques on a qcm surface related to acetaldehyde responses in the gas phase. Sensors 2018, 18, 3942. [CrossRef]

7. Walkowiak, J.; Gradzielski, M.; Zauscher, S.; Ballauff, M. Interaction of Proteins with a Planar Poly (acrylic acid) Brush: Analysis by Quartz Crystal Microbalance with Dissipation Monitoring (QCM-D). Polymers 2021, 13, 122. [CrossRef]

8. Janshoff, A.; Galla, H.J.; Steinem, C. Piezoelectric mass-sensing devices as biosensors-An alternative to optical biosensors? Angew. Chem. Int. Ed. 2000, 39, 4004-4032. [CrossRef]

9. Agostini, M.; Amato, F.; Vieri, M.L.; Greco, G.; Tonazzini, I.; Baroncelli, L.; Cecchini, M. Glial-fibrillary-acidic-protein (GFAP) biomarker detection in serum-matrix: Functionalization strategies and detection by an ultra-high-frequency surface-acoustic-wave (UHF-SAW) lab-on-chip. Biosens. Bioelectron. 2021, 172, 112774. [CrossRef]

10. Greco, G.; Agostini, M.; Cecchini, M. Ultra-high-frequency Love surface acoustic wave device for real-time sensing applications. IEEE Access 2020, 8, 112507-112514. [CrossRef]

11. Agostini, M.; Greco, G.; Cecchini, M. Full-SAW microfluidics-based lab-on-a-chip for biosensing. IEEE Access 2019, 7, 70901-70909. [CrossRef]

12. Piovarci, I.; Hianik, T.; Ivanov, I.N. Detection of chymotrypsin by optical and acoustic methods. Biosensors 2021, 11, 63. [CrossRef] [PubMed]

13. Piovarci, I.; Melikishvili, S.; Tatarko, M.; Hianik, T.; Thompson, M. Detection of Sub-Nanomolar Concentration of Trypsin by Thickness-Shear Mode Acoustic Biosensor and Spectrophotometry. Biosensors 2021, 11, 117. [CrossRef] [PubMed]

14. Dizon, M.; Tatarko, M.; Szabo, K.; Hianik, T. Application of high-resolution ultrasonic spectroscopy for detection of the plasmin activity toward $\beta$-casein. Food Chem. 2021, 353, 129373. [CrossRef]

15. Farokhzad, N.; Tao, W. Materials chemistry-enabled platforms in detecting sexually transmitted infections: Progress towards point-of-care tests. Trends Chem. 2021, 3, 589-602. [CrossRef]

16. Fracassetti, D.; Di Canito, A.; Bodon, R.; Palmowska, N.; Vigentini, I.; Foschino, R.; Tirelli, A. Light-struck taste in white wine: Reaction mechanisms, preventive strategies and future perspectives to preserve wine quality. Trends Food Sci. Technol. 2021, 112, 547-558. [CrossRef]

17. Di Gennaro, S.F.; Matese, A.; Mancin, M.; Primicerio, J.; Palliotti, A. An open-source and low-cost monitoring system for precision enology. Sensors 2014, 14, 23388-23397. [CrossRef]

18. Tzima, K.; Brunton, N.P.; Rai, D.K. Qualitative and Quantitative Analysis of Polyphenols in Lamiaceae Plants-A Review. Plants 2018, 7, 25. [CrossRef]

19. Cory, H.; Passarelli, S.; Szeto, J.; Tamez, M.; Mattei, J. The Role of Polyphenols in Human Health and Food Systems: A Mini-Review. Front. Nutr. 2018, 5, 87. [CrossRef] [PubMed]

20. González-Burgos, E.; Gómez-Serranillos, M.P. Effect of Phenolic Compounds on Human Health. Nutrients 2021, 13, 3922. [CrossRef]

21. Abreu, T.; Perestrelo, R.; Bordiga, M.; Locatelli, M.; Daniel Coïsson, J.; Câmara, J.S. The Flavor Chemistry of Fortified Wines-A Comprehensive Approach. Foods 2021, 10, 1239. [CrossRef] [PubMed]

22. Razgonova, M.; Zakharenko, A.; Pikula, K.; Manakov, Y.; Ercisli, S.; Derbush, I.; Golokhvast, K. LC-MS/MS Screening of Phenolic Compounds in Wild and Cultivated Grapes Vitis amurensis Rupr. Molecules 2021, 26, 3650. [CrossRef] [PubMed]

23. Suo, H.; Shishir, M.R.I.; Xiao, J.; Wang, M.; Chen, F.; Cheng, K.W. Red Wine High-Molecular-Weight Polyphenolic Complex: An Emerging Modulator of Human Metabolic Disease Risk and Gut Microbiota. J. Agric. Food Chem. 2021, 69, 10907-10919. [CrossRef] [PubMed]

24. Gutiérrez-Escobar, R.; Aliaño-González, M.J.; Cantos-Villar, E. Wine polyphenol content and its influence on wine quality and properties: A review. Molecules 2021, 26, 718. [CrossRef] [PubMed] 
25. Gonçalves, B.; Falco, V.; Moutinho-Pereira, J.; Bacelar, E.; Peixoto, F.; Correia, C. Effects of elevated $\mathrm{CO}_{2}$ on grapevine (Vitis vinifera L.): Volatile composition, phenolic content, and in vitro antioxidant activity of red wine. J. Agric. Food Chem. 2009, 57, 265-273.

26. Di Egidio, V.; Sinelli, N.; Giovanelli, G.; Moles, A.; Casiraghi, E. NIR and MIR spectroscopy as rapid methods to monitor red wine fermentation. Eur. Food Res. Technol. 2010, 230, 947-955. [CrossRef]

27. Garcia-Torres, R.; Ramírez-Rodrigues, M.M.; Pérez-Alva, A. Polyphenolic Profile of Orange Wines. Curr. Dev. Nutr. 2021, 5 (Suppl. 2), 1158. [CrossRef]

28. Fermo, P.; Comite, V.; Sredojević, M.; Ćirić, I.; Gašić, U.; Mutić, J.; Tešić, Ž. Elemental Analysis and Phenolic Profiles of Selected Italian Wines. Foods 2021, 10, 158. [CrossRef]

29. Mierczynska-Vasilev, A.; Smith, P.A. Surface modification influencing adsorption of red wine constituents: The role of functional groups. Appl. Surf. Sci. 2016, 386, 14-23. [CrossRef]

30. Mierczynska-Vasilev, A.; Smith, P.A. Adsorption of wine constituents on functionalized surfaces. Molecules 2016, 21, 1394. [CrossRef]

31. Karczmarczyk, A.; Haupt, K.; Feller, K.H. Development of a QCM-D biosensor for Ochratoxin A detection in red wine. Talanta 2017, 166, 193-197. [CrossRef]

32. Wang, S.; Mantilla, S.M.O.; Smith, P.A.; Stokes, J.R.; Smyth, H.E. Astringency sub-qualities drying and pucker are driven by tannin and pH-Insights from sensory and tribology of a model wine system. Food Hydrocol. 2020, 109, 106109. [CrossRef]

33. Guerreiro, J.R.L.; Teixeira, N.; De Freitas, V.; Sales, M.G.F.; Sutherland, D.S. A saliva molecular imprinted localized surface plasmon resonance biosensor for wine astringency estimation. Food Chem. 2017, 233, 457-466. [CrossRef]

34. Lei, L.; Tang, Y.; Zheng, J.; Ma, G.; Zhou, Z. Influence of two polyphenols on the structure and lubrication of salivary pellicle: An in vitro study on astringency mechanism. Friction 2021, 10, 167-178. [CrossRef]

35. Wang, S.; Mantilla, S.M.O.; Smith, P.A.; Stokes, J.R.; Smyth, H.E. Tribology and QCM-D approaches provide mechanistic insights into red wine mouthfeel, astringency sub-qualities and the role of saliva. Food Hydrocol. 2021, 120, 106918. [CrossRef]

36. Iturmendi, N.; Duràn, D.; Marìn-Arroyo, M.R. Fining of red wines with gluten or yeast extract protein. Int. J. Food Sci. Technol. 2010, 45, 200-207. [CrossRef]

37. Cosme, F.; Ricardo-da-Silva, J.M.; Laureano, O. Interactions between protein fining agents and proanthocyanidins in white wine. Food Chem. 2008, 106, 536-544. [CrossRef]

38. Haslam, E.; Lilley, T.H.; Warminski, E.; Liao, H.; Cai, Y.; Martin, R.; Gaffney, S.H.; Goulding, P.N.; Luck, G. Polyphenol complexation. In Phenolic Compounds in Food and Their Effects on Health; Ho, C.T., Lee, C.Y., Huang, M.T., Eds.; ACS Symposium Series; American Chemical Society: Washington, DC, USA, 1992; pp. 8-50.

39. Kawamoto, H.; Nakatsubo, F. Effects of environmental factors on two-stage tannin-protein coprecipitation. Phytochem 1997, 46, 379-483. [CrossRef]

40. Sarni-Manchado, P.; Deleris, A.; Avallone, S.; Cheynier., V.; Moutounet, M. Analysis and characterization of wine condensed tannins precipitated by proteins used as fining agent in enology. Am. J. Enol. Viticul. 1999, 50, 81-86.

41. Wang, X.; Ho, C.T.; Huang, Q. Investigation of adsorption behavior of (-)-epigallocatechin gallate on bovine serum albumin surface using quartz crystal microbalance with dissipation monitoring. J. Agric. Food Chem. 2007, 55, 4987-4992. [CrossRef]

42. Dixon, M.C. Quartz crystal microbalance with dissipation monitoring: Enabling real-time characterization of biological materials and their interactions. J. Biomol. Techn. JBT 2008, 19, 151

43. Kusuda, M.; Hatano, T.; Yoshida, T. Water-soluble complexes formed by natural polyphenols and bovine serum albumin: Evidences from gel electrophoresis. Biosci. Biotechnol. Biochem. 2006, 70, 152-160. [CrossRef]

44. Harbertson, J.F.; Kilmister, R.L.; Kelm, M.A.; Downey, M.O. Impact of condensed tannin size as individual and mixed polymers on bovine serum albumin precipitation. Food Chem. 2014, 160, 16-21. [CrossRef]

45. Lei, X.; Zhu, Y.; Wang, X.; Zhao, P.; Liu, P.; Zhang, Q.; Chen, T.; Yuan, H.; Guo, Y. Wine polysaccharides modulating astringency through the interference on interaction of flavan-3-ols and BSA in model wine. Int. J. Biol. Macromol. 2019, 139, 896-903. [CrossRef]

46. Harbertson, J.F.; Mireles, M.; Yu, Y. Improvement of BSA tannin precipitation assay by reformulation of resuspension buffer. Am. J. Enol. Viticul. 2014, 10, 16-21. [CrossRef]

47. Jauregi, P.; Olatujoye, J.B.; Cabezudo, I.; Frazier, R.A.; Gordon, M.H. Astringency reduction in red wine by whey proteins. Food Chem. 2016, 199, 547-555. [CrossRef] [PubMed]

48. Olatujoye, J.B.; Methven, L.; Jauregi, P. Effect of $\beta$-lactoglobulin on perception of astringency in red wine as measured by sequential profiling. LWT Food Sci. Technol. 2020, 130, 109611. [CrossRef]

49. Kaneda, H.; Watari, J.; Takashio, M.; Okahata, Y. Measuring astringency of beverages using a quartz-crystal microbalance. J. Am. Soc. Brew. Chem. 2003, 61, 119-124.

50. Yan, Q.; Bennick, A. Identification of histatins as tanning-binding proteins in human saliva. Biochem. J. 1995, 311, 341-347. [CrossRef]

51. Shraberg, J.; Rick, S.W.; Rannulua, N.; Cole, R.B. A study of procyanidin binding to Histatin 5 using Electrospray Ionization Tandem Mass Spectrometry (ESI-MS/MS) and molecular simulations. Phys. Chem. Chem. Phys. 2015, 17, 12247-12258. [CrossRef]

52. Wróblewski, K.; Muhandiram, R.; Chakrabartty, A.; Bennick, A. The molecular interaction of human salivary histatins with polyphenolic compounds. Eur. J. Biochem. 2001, 268, 4384-4397. [CrossRef] [PubMed]

53. Baxter, N.; Lilley, T.H.; Haslam, E.; Williamson, M.P. Multiple interactions between polyphenols and salivary proline-rich protein repeat result in complexation and precipitation. Biochemistry 1997, 36, 5566-5577. [CrossRef] [PubMed] 
54. Bacon, J.R.; Rhodes, M.J. Binding affinity of hydrolyzable tannins to parotid saliva and to proline-rich proteins derived from it. J. Agric. Food Chem. 2000, 48, 838-843. [CrossRef] [PubMed]

55. Saftics, A.; Kurunczi, S.; Peter, B.; Szekacs, I.; Ramsden, J.J.; Horvath, R. Data evaluation for surface-sensitive label-free methods to obtain real-time kinetic and structural information of thin films: A practical review with related software packages. Adv. Coll. Interf. Sci. 2021, 294, 102431. [CrossRef]

56. International Organisation of Vine and Wine (OIV). Compendium of International Methods of Wine and Must Analysis. Edition 2021, Volume 1. Available online: https://www.oiv.int/en/technical-standards-and-documents/methods-of-analysis/ compendium-of-international-methods-of-analysis-of-wines-and-musts (accessed on 3 November 2021).

57. Venturi, F.; Sanmartin, C.; Taglieri, I.; Xiaoguo, Y.; Quartacci, M.F.; Sgherri, C.; Andrich, G.; Zinnai, A. A kinetic approach to describe the time evolution of red wine as a function of packaging conditions adopted: Influence of closure and storage position. Food Packag. Shelf Life 2017, 13, 44-48. [CrossRef]

58. Asano, K.; Shinagawa, K.; Hashimoto, N. Characterization of haze-forming proteins of beer and their roles in chill haze formation. J. Am. Soc. Brew. Chem. 1982, 40, 147-154. [CrossRef]

59. Siebert, K.J.; Troukhanova, N.V.; Lynn, P.Y. Nature of polyphenol-protein interactions. J. Agric. Food Chem. 1996, 44, 80-85. [CrossRef]

60. Bandyopadhyay, P.; Ghosh, A.K.; Ghosh, C. Recent developments on polyphenol-protein interactions: Effects on tea and coffee taste, antioxidant properties and the digestive system. Food Funct. 2012, 3, 592-605. [CrossRef]

61. Rawel, H.M.; Czajka, D.; Rohn, S.; Kroll, J. Interactions of different phenolic acids and flavonoids with soy proteins. Int. J. Biol. Macromol. 2002, 30, 137-150. [CrossRef]

62. Motiejunas, D.; Wade, R.C. Structural, Energetic, and Dynamic Aspects of Ligand-Receptor Interactions. In Comprehensive Medicinal Chemistry II; Taylor, J.B., Triggle, D.J., Eds.; Elsevier: Amsterdam, The Netherlands, 2007; pp. 193-213.

63. Medda, L.; Monduzzi, M.; Salis, A. The molecular motion of bovine serum albumin under physiological conditions is ion specific. Chem. Comm. 2015, 51, 6663-6666. [CrossRef]

64. Alihosseini, F. Plant-based compounds for antimicrobial textiles. In Antimicrobial Textiles; Woodhead Publishing: Sawstone, UK, 2016; pp. 155-195.

65. Semenova, M.G.; Antipova, A.S.; Belyakova, L.E. Food protein interactions in sugar solutions. Curr. Opin. Coll. Interf. Sci. 2002, 7, 438-444. [CrossRef]

66. Seddon, T.J.; Downey, M.O. Comparison of analytical methods for the determination of condensed tannins in grape skin. Aust. J. Grape Wine Res. 2008, 14, 54-61. [CrossRef]

67. Sharma, P.; Ghosh, A.; Tudu, B.; Sabhapondit, S.; Baruah, B.; Tamuly, P.; Bandyopadhyay, R. Monitoring the fermentation process of black tea using QCM sensor based electronic nose. Sens. Actuators B Chem. 2015, 219, 146-157. [CrossRef] 